\title{
Analysis Of Global Trends In Building Ubiquitous Information Technology Market Environment
}

Yangkoo Kang, (E-mail: ykang3@campus.hpu.edu), Hawaii Pacific University Joseph Chunghi Ha, (E-mail: jha@hpu.edu), Hawaii Pacific University

\begin{abstract}
This study found that each country, in order to propel the Global Ubiquitous Information Technology (IT) Business Market, has initiated strategies that utilize its own strengths in the IT industry. Ubiquitous information technology is recognized as a new strategy to propel the information industry and to enhance country's competitive power in the global information economy. IT companies in leading IT countries including the United States, Japan, and several European countries engage in active investment and research through a cooperative system among the industry, universities, and the government. Transition to a ubiquitous society may be a quiet revolution, but the reaching effects of the transition will be tremendous. Countries and enterprises should sense what consumers and market demand and should respond to it quickly. Only when countries and enterprises catch the latest information and process it for application, they can expect to succeed.
\end{abstract}

\section{INTRODUCTION}

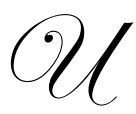

biquitous information technology (Ubiquitous IT) is recognized as a new strategy to propel the information industry and to enhance country's competitive power in the global information economy. Governments and enterprises of leading IT countries compete intensely to build a ubiquitous environment and to preoccupy related markets. Especially, IT companies in leading IT countries including the United States, Japan, and several European countries engage in active investment and research through a cooperative system among the industry, universities, and the government.

As digital convergence is in progress in fixed and mobile communication networks, devices and services, the word "Ubiquitous," which has been understood in the abstract, is being embodied. Also, various projects have been developed by leading IT companies and universities. In that, they are developing a new business model and trying to preoccupy the market by testing experimental products and services.

Different viewpoints present different images of future services that would be available in a ubiquitous society. However, it is important and necessary for private companies and public sectors to prepare for the future services because the services are expected to create new business profits, increase customer satisfaction, renovate management systems, and improve the quality of life.

Transition to a ubiquitous society may be a quiet revolution, but the reaching effects of the transition will be tremendous. A quite level of advances and changes has been already made in underlying social structure so that a country or an enterprise can not expect to place oneself in the future IT market if one does not sense the changes in paradigm or fails to cope with the changes.

\section{PURPOSE AND SIGNIFICANCE OF STUDY}

Ubiquitous computing means that the boundary between real space and virtual space has no meaning. Virtual space is incorporated into real space through network. As virtual space embodied by IT companies is incorporated into real space, such as a building constructed by a construction company, new ubiquitous space is created, and digital home companies are blowing various vital powers into it to make human life more bountiful[1][2]. Just like the Internet connects computers that are apart, a ubiquitous society connects lots of physical objects that exist isolated in the environment[3]. Again, transition to a ubiquitous society may be soundless, but the reaching effects of the 
transition will be beyond our imagination.

This study found that each country, in order to propel the Global Ubiquitous Market, has initiated strategies that utilize its own strengths in the IT industry. For example, it is the government that is leading the force toward the Global Ubiquitous Market in Japan. In terms of developing government-driven policies, therefore, the case of Japan provides a good example. Meanwhile, private companies are the leading force toward the Global Ubiquitous Market in European countries.

A new business model with marketability can be found by analyzing the latest R\&D (Research \& Development) cases of European companies. European cases also provide some hints for developing services to improve the quality of life and welfare of the people.

\section{CHANGE IN THE ENVIRONMENT OF SOUNDLESS REVOLUTION : "IT BUSINESS MARKET"}

Here, we will consider the future envisioned for each subject in the wake of global ubiquitous business market from the perspective of government, enterprise and individual.

\section{Presentation Of Future Envisioned From The Perspective Of Ubiquitous Government}

First, the future can be envisioned from two perspectives in terms of ubiquitous government (u-government).

The first perspective states that the public-oriented customized service would be provided discretionarily in real time without any constraint on the time and space. It purports that services environment that is fast and accessible at any time will be provided on the basis of broad band integrated network, and services will be able to be consumed easily and conveniently in any time and space without any constraint on time and space on the basis of the wireless and the mobile foundation[4]. This implies that space converging service connecting both online and offline and the intelligent service founded on sensing and chip will be consumed naturally.

The second perspective posits that the operating cost of government may be saved by building an efficient work processing environment. In short, efforts and costs to produce and search for various documents can be saved by supporting the work that connects both online and offline and supplying the teleportation service that support 'my ubiquitous office' environment.

\section{Presentation Of Future Envision From The Perspective Of Ubiquitous Business}

The future image of ubiquitous business (u-business) can be presented, and it means that the computerization that currently focuses only on the transaction, such as B2B, B2C and so on, will include all processes of more expanded production, distribution, transaction and stock management. Therefore, it implies that customized services tailored to the needs of site, which is more convenient and intelligent, is provided in real time to consumers by optimizing the process of production management of company currently in progress.

The envisioned future of company(ubiquitous business: u-business) can be put forth, and it means that the current computerization that have focused on transaction, such as B2B, B2C, etc, will handle entire process of production, distribution, transaction and inventory management in order to maximize the process of product management and supply intelligent services customized for work in real time[5].

In other words, RFID(Radio Frequency Identification) will be applied to production process, maximizing the production by expanding the raw material using rate, increasing the operation rate, improving the quality, shortening the delay in order, reducing defect rate and others[6].

Moreover, Warehouse Management System (WMS) will assure that the product information and location management are able to be figured out automatically in the whole process ranging from replenishment to withdrawal, maximizing the efficiency by shortening the unloading time, reducing the error and mistakes in loading, enhancing the accuracy of replenishment and withdrawal, preventing the loss and theft and so on. 
Product Life Cycle Management (PLM) will also assure increased customer satisfaction, safety inventory management and so on, using such product cycle as the planning, production, after-sales servicing, and disposal of product.

Figure 1: The Size Of International RFID Market (In Billion U.S. Dollar)

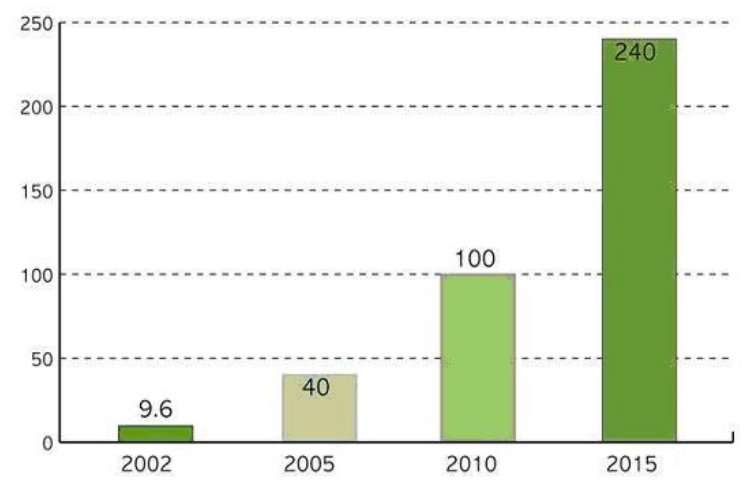

\section{Presentation Of Future Envisioned From The Perspective Of Ubiquitous Life}

The objective here is to implement the welfare society founded on the Ubiquitous where the support is provide to ensure the relief of workload for simple labor, such as housework, build the social safety net by embedding various safeguarding features in objects to prevent accidents, and expand the convenience and benefit for the elderly and disabled through various services provided by intelligent public facilities[7].

\section{TREND OF UBIQUITOUS IT PROJECT OF MAJOR COUNTRIES \& ANALYSIS ON CASES}

The Ubiquitous IT is being recognized as a new strategy to build a new knowledge-based country and to enhance the country's competitive power in the information industry. Governments and enterprises of IT countries compete intensely to build a ubiquitous environment and to preoccupy related markets. Especially, the United States, Japan and European countries engage in active investment and research through a cooperative system among the industry, universities, and the government.

Figure 2: Evolution Of Computing Concept

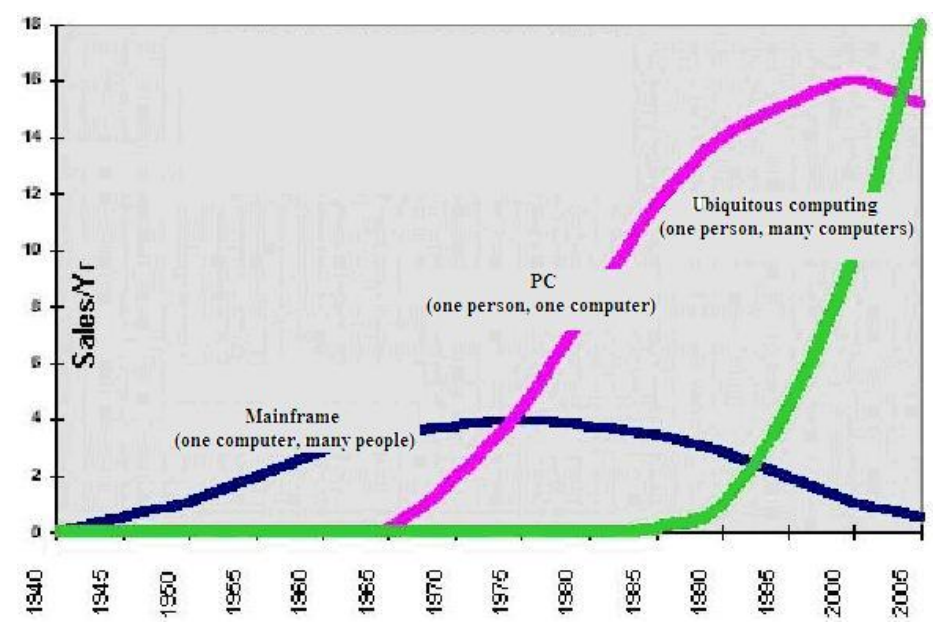


As digital convergence is in progress in fixed and mobile communication networks, devices and services, the word "Ubiquitous," which has been understood in the abstract, is being embodied. Also, various projects have been developed by leading IT companies and universities[8][9]. In that, they are developing a new business model and trying to preoccupy the market by testing experimental products and services.

Table 1

Comparison of Common Properties of 5 Major of Ubiquitous Computing Founded on 4 Major IT Core Technologies

\begin{tabular}{|c|c|c|c|c|}
\hline Name of Project & Property by Project & \begin{tabular}{|l|} 
Core \\
Technology
\end{tabular} & Common Property & \\
\hline EasyLiving (MS) & Mobility + Intelligent-type & $\begin{array}{l}\text { Sensor } \\
\text { Technology }\end{array}$ & \multirow{2}{*}{$\begin{array}{l}\text { Context aware } \\
\text { Services, } \\
\text { Autonomous } \\
\text { Services, Location } \\
\text { and Role Services, } \\
\text { Location Sensing } \\
\text { Services etc. }\end{array}$} & \multirow{2}{*}{$\begin{array}{l}\text { Autonomous-Type } \\
\text { (Autonomous Sensing, } \\
\text { Adaptability to Environment, } \\
\text { Cooperation, Control, } \\
\text { Perception of Situation) }\end{array}$} \\
\hline $\begin{array}{l}\text { Smart-Its } \\
\text { (EU, ETH etc.) }\end{array}$ & $\begin{array}{l}\text { Wireless Communication }+ \\
\text { Cooperative Perception of } \\
\text { Situation }\end{array}$ & $\begin{array}{l}\text { Small Chip } \\
\text { Technology }\end{array}$ & & \\
\hline $\begin{array}{l}\text { Smart Dust (UC } \\
\text { Berkeley) }\end{array}$ & $\begin{array}{l}\text { Autonomous sensing }+ \\
\text { Communication Platform }\end{array}$ & $\begin{array}{l}\text { MEMS } \\
\text { Technology }\end{array}$ & $\begin{array}{l}\text { NFC through Blutus, } \\
\text { fiber optic, RF, }\end{array}$ & $\begin{array}{l}\text { Communication platform } \\
\text { (Networking, }\end{array}$ \\
\hline CoolTown (HP) & $\begin{array}{l}\text { Real Web } \\
\text { (co-existence of human being, } \\
\text { objects and space) }\end{array}$ & $\begin{array}{l}\text { Near Distance } \\
\text { Wireless } \\
\text { Technology }\end{array}$ & $\begin{array}{l}\text { Moros code } \\
\text { Communication, etc }\end{array}$ & Internet Connectivity) \\
\hline Auto-ID (MIT) & $\begin{array}{l}\text { Intelligence + ID + internet } \\
\text { connectivity }\end{array}$ & $\begin{array}{l}\text { Complex } \\
\text { Technology }\end{array}$ & $\begin{array}{l}\text { Wearable, Portable, } \\
\text { Attachable, Embeddable, } \\
\text { etc. }\end{array}$ & $\begin{array}{l}\text { Mobility } \\
\text { (Super tiny Computing Object) }\end{array}$ \\
\hline
\end{tabular}

\section{Trend Of Ubiquitous IT Project In The United States Of America \& Analysis On Cases}

The United States commenced the research and development vigorously to realize the ubiquitous computing in 1991 in order to maintain the competitive advantage of information \& telecommunication industry for ubiquitous environment, and has been spearheading the ubiquitous revolution. The basic direction of relevant policies is to embody ubiquitous computing by combining BT and NT on the basis of super high tech computer and software technology.

For the major part, ubiquitous computing technology and early and partial development of application have been emphasized, and Human Computer Interface (HCI) technology and development of standard which can naturally integrate routine daily space and computer, is being recognized as core element.

In addition, the research project related to ubiquitous computing in the United States is mostly characterized by the systematic role-sharing and cooperation among related governmental organizations, private sector enterprises and research institutes. Though Washington emphasized networking research, such as the Next Generation Internet (NGI) until 2000, it has expanded the investment in research and development again which are related to high performance computing since 2001. Bush Administration raised the budget allocated to ubiquitous computing to approximately $\$ 1.867$ million in 2004[10].

Furthermore, the role-sharing and cooperation among governmental organizations are very critical in preventing the overlapped investment and ensuring effective and efficient research and development. Moreover, it is considered that this systematic mutual cooperation will positively assist private sector companies in their trying to make inroads into global markets and preoccupy the global ubiquitous market that has ubiquitous environment.

That is because the absence of mutually connected plans or coordinating organizations are likely to cause much overlapping investment and conflict related to the work sharing in the future though governmental organizations, private sector businesses and many organizations in some European and Asian countries which are moving forward with ubiquitous computing projects have been establishing polices and planning research and development in relation to ubiquitous computing. 
The United States is leading technologies in nearly all fields related to ubiquitous computing. They put emphasis on the early and partial application development and recognize $\mathrm{HCI}$ (Human Computer Interface) and development of standard as core element technology which is capable of naturally converging, specifically, the routine daily space and computer.

The United States aims to develop Peta-grade high performance computing technology in the hardware field as part of its strategy for technology development. Next, it is aiming to achieve the global leadership in the field of convergence technology linking the super high tech computing and super highway network by securing Peta-grade communication technology for networking. In addition, it is also moving ahead with hybrid communication technology capable of accessing via both wired and wireless network anywhere and anytime based on all-optical network, and is developing sensor network technology to connect billions of embedded sensors[11].

The software research and development is being proceeded ahead in three fields, namely, user interface technology, component software, embedded application software development.

\section{Trend Of Ubiquitous IT Project Of European Union (EU) \& Analysis On Cases}

Considering that EU is working like an independent government in Europe, it is not easy to apply the analysis for U.S and Japan to policies of EU.

The 'Disappearing Computing Initiative' implemented as part of Information Society Technology (IST) of EU for two years from 2001 with the financial support of Future Technological Plan (FET) is composed of 16 independent projects. This project ultimately aims to develop information artifacts capable of computing and networking through commonly available objects embedded with small sensors, etc and build an environment that supports the daily activities of human beings through the perception of cooperative situation based on the communication between intelligent objects[10].

Europe is exploring to cope with the ubiquitous revolution by deriving the concept and technology related to the application of computer in the future through this project.

In addition, projects related to various ubiquitous computing are characterized by two things at large, which each country is moving forward under the leadership of EU.

One distinction of European ubiquitous computing project from that of U.S. is its conspicuous research on computing technology to create welfare environment for every day life, rather than the industry. In short, EU focuses on the application of information technology to support the daily lives rather than the application for business purpose.

The other distinction is its research is dedicated to the service and product development that focuses on the short distance communication among objects rather than the computing environment which concentrates to the server founded on the Internet. Like that, each country is making endeavors to implement the ubiquitous policy and project to maximize the strength in consideration of business and national conditions. EU began to drive its research and development on the ubiquitous technology in 2001 as part of IST with the financial support of FET.

EU is coping with the ubiquitous revolution by implementing the under mentioned 16 projects mainly through the 'Disappearing Computing Initiative'.

1. 2WEAR : Computer which is adaptable, expandable, wearable, portable while acting.

2. GROCER : Grocery which sells goods embedded with location-founded electronic tag.

3. e-Gadgets : Creation of Gazet World through component-founded autonomous information artifact.

4. Smart-Its : Autonomous information artifact capable of mutually-connectable collective perception .

5. Oresteia : Multi-purpose information artifact module adaptable to the interaction with human being.

6. Ambient Agoras : Embodying social information market by providing dynamic information cluster environment of various worlds.

7. Paper++ : Electronic exchange more useful than paper as an electronic learning material embedded with sensor and location-founded apparatus.

8. Accord : Tool to build, operate and manage home environment centered on visible interface. 
9. Gloss : Global type autonomous electronic space which transformed into intelligent environment in the wake of disappearance of computer.

10. Workspace : The computing spatial environment that supports the dispersion tasks through component.

11. SOB : Embodying the interface founded on the sound and gesture for objects capable of interacting with human beings.

12. Ficom : Converting minute structure of fiber into transistor and applying computing function to it in order to embody as information artifacts for every day life.

13. Mime : Embodying an friendly environment centered around individual through artifacts via multiple information medium.

14. Feel : Providing a place-oriented service environment founded on mobile technology for customization and entertainment.

15. Interliving : Embodying generation converging interface founded on dialogue method which is dedicated to promote quality family life.

16. Shape : Embodying a variety of mixed type information environment that suits public spaces.

The first purpose of this project is to develop tools embedded with smart functions for routine objects and such methods. Second, this projects aims to study new functions and usage for the interaction among routine objects. Finally, it aims to study whether the smart objects environment can blend with the lives of human beings amicably.

The strategy of EU to respond to the Ubiquitous is to develop information artifacts with more advanced information processing and information exchanging capability added to unique function of objects by embedding sensor, actuator(or driver), processors, and so on, in them.

\section{Trend Of Ubiquitous IT Project Of Japan \& Analysis On Cases}

In Japan, the government has spearheaded the effort at IT computerization earlier than any other Asian countries, and its ubiquitous computing is characterized by its government-led and enterprise-led projects, too.

Specifically, TRON(Real-time Operating System Nucleus) project heralded the research on the ubiquitous technology which began by Professor Sakamura Gen at Tokyo University in 1984. He predicted that the systematic interface technology for object to object(O2O), namely, all tools, apparatuses, equipment and objects that constitute the environment of our lives would be computerized in the computerized society in the future beyond the person to person(P2P) and drove the TRON project[12].

At the moment, the Ubiquitous-related market in Japan is expanding gradually, too. The Ubiquitous-related market in Japan which was worth only 29 trillion Yen in 2003 is expected to expand into a gigantic market worth 59 trillion Yen in 2007 and 88 trillion Yen in 2010, respectively. Moreover, the Japanese government is currently driving 3 major projects for ubiquitous network, which include 'super tiny chip networking project', 'my terminal project for anything', 'anywhere-networking project'. It is moving ahead with the research and development aiming to secure related element technology by the end of 2006[13][14].

The policy-making in Japan has been preceded by long term review through sessions. The session which is attended by experts from private sector and government sector is committed to promoting the participation of private sector and come up with realistic policies from the stage of policy review[15]. This system of Japan is every effective for policy-making, considering that requirements of people of various interest need to be converged to ensure a successful policy-making by companies.

U-Japan policy is more of a vision of society than the vision of technology. Japan is investing efforts at governmental level, given that it is very critical for Japan to build a well-organized ubiquitous network and create lots of examples for application in the quickest fashion[16].

A comprehensive plan to implement has been established since 2001 by setting up the investigative research association composed of experts under the leadership of government. Among major plans implemented by the research association, the first thing is 'super tiny chip network project'. It aims to develop a network technology that enables the coordination among 10 billion terminals and control of them by embedding the microchip in clothes, documents, security and brand product. Second, it aims to develop the technology that enables people to 
instantaneously use any terminal like their own through the non-contact type card called 'Go to My Terminal Project for anything'[17].

Finally, it is the project called' 'With the Network Project anywhere', which is connected to the network at any time and at any place, embodying the environment where the communication service identical to the one provided to office is implemented. Eventually, unlike the United States, Japan is devoting itself to the micro sensor technology to achieve the final stage of E-Japan, which is 'U-Japan'.

Table 2 represents the summary of technology to be developed, which countries on the globe are driving.

Table 2

Comparison Of Concept Of Ubiquitous \& The Field Of Technological Development

\begin{tabular}{|c|c|c|c|c|c|}
\hline Type & $\begin{array}{c}\text { United States } \\
\text { of America } \\
\text { (USA) }\end{array}$ & $\begin{array}{c}\text { European } \\
\text { Union } \\
\text { (EU) }\end{array}$ & Japan & Singapore & South Korea \\
\hline Method of Expression & $\begin{array}{c}\text { Ubiquitous } \\
\text { Computing; } \\
\text { Pervasive } \\
\text { Computing }\end{array}$ & $\begin{array}{c}\text { Disappearing } \\
\text { Computer; } \\
\text { Ambient } \\
\text { Computing }\end{array}$ & $\begin{array}{c}\text { Ubiquitous } \\
\text { Network }\end{array}$ & $\begin{array}{c}\text { Pervasive } \\
\text { Infra }\end{array}$ & $\begin{array}{c}\text { Ubiquitous } \\
\text { Appliance }\end{array}$ \\
\hline $\begin{array}{c}\text { Autonomous, } \\
\text { service } \\
\text { embodied by } \\
\text { computing } \\
\text { device }\end{array}$ & $\begin{array}{c}\text { Autonomous } \\
\text { cooperation by } \\
\text { means of } \\
\text { information } \\
\text { and artifacts }\end{array}$ & $\begin{array}{c}\text { connection to } \\
\text { the network } \\
\text { regardless of } \\
\text { the space, by } \\
\text { means of tiny } \\
\text { chip, smart } \\
\text { card, context } \\
\text { roaming }\end{array}$ & $\begin{array}{c}\text { construction } \\
\text { of integrated } \\
\text { network that } \\
\text { connects the } \\
\text { wireless } \\
\text { LAN, mobile } \\
\text { phone, } \\
\text { broadband } \\
\text { Internet }\end{array}$ & $\begin{array}{c}\text { WiBro service } \\
\text { portable Internet) } \\
\text { ground wave } \\
\text { digital TV, DMB } \\
\text { service(TV in my } \\
\text { hand), } \\
\text { IT SoC, Telematics } \\
\text { service, } \\
\text { W-CDMA } \\
\text { (3 generation } \\
\text { mobile } \\
\text { communication }\end{array}$ \\
\hline $\begin{array}{c}\text { Field of Intensive } \\
\text { Development }\end{array}$ & $\begin{array}{c}\text { Computer } \\
\text { Device }\end{array}$ & $\begin{array}{c}\text { Everyday } \\
\text { Object }\end{array}$ & Network & $\begin{array}{c}\text { National } \\
\text { Information } \\
\text { Infra }\end{array}$ & $\begin{array}{c}\text { Computer Device } \\
\text { \& Appliance }\end{array}$ \\
\hline
\end{tabular}

\section{UBIQUITOUS IT OF COMPANIES: MEASURE TO COPE WITH THE CHANGE IN MARKET ENVIRONMENT}

Companies should put forth a vision to evolve into globally-oriented companies using their latent energy as leading IT companies by taking advantage of Ubiquitous revolution which is a new and great revolution as a springboard for development[18]. They should set up strategic plan to secure technology and industrial competitive advantage as well as effectively organizing corporate environment. Companies should maintain the current state of product and service development and have accurate insight required to analyze governmental policies appropriately and then forecast[19][20].

Moreover, it is very critical to compare and analyze the progress of ubiquitous IT project by the country for the profit of companies. In planning, the loss ensuing from the preoccupation of new IT business market should be minimized and the benefit of investment should be maximized by analyzing the Japanese model which has the Ubiquitous IT construction model at governmental level and the European model which is characterized by the development of products and services to support daily lives for the purpose of abundant lives of people and then applying both models to the direction of new IT business market.

In addition, corporate policies should be established newly to ensure the optimal utilization of current infrastructure and sectors which have competitive advantages and measures to expand global IT technological markets should be explored and research \& development plans should be established. Corporate strategy for core global 
ubiquitous business market, which this study proposes, is to innovate social system, secure a footing to gain profits from new business model, link the ubiquitous IT business market of companies with the plan driven by government, promote the creation synergy by deriving ubiquitous core technology and reviewing the associated structure, so that the ubiquitous IT would be introduced to the society and corporate societies across the board to ensure the chain reaction of innovation. Furthermore, it is meaningful in that it makes all resources of companies and country intelligent and networked to create a practical IT environment where all people can have access to services at any time and any place that they need for everyday lives, bringing together all the energy of country and companies to achieve their shared goals.

\section{SUMMARY AND CONCLUSIONS}

Ubiquitous computing means that the border between the real space and virtual space is getting blurred and meaningless. Virtual space is naturally converged into the living space through the network. As the real space called architecture built by construction companies is combined with virtual space embodied by IT companies, new ubiquitous space is created and various forms of vitality is added to it, and digital home companies are breathing various forms of vitality into it, making the lives of human beings more affluent and abundant. If the Internet linked the computers which remain isolated on desks, the Ubiquitous links countless number of physical objects which exist far away from one another in the environment. The Ubiquitous which we perceive is a quiet revolution, but its spillover effect will be really strikingly shocking. The trend of study of advanced countries and global IT companies indicates clearly that the ubiquitous environment is imminent and measures to cope with that are urgently called for. Based on that, it is important that we pave the way for our country and companies to leap into the world's top country and companies by ensuring that government and private sector companies work together and share their roles in an appropriate fashion to spearhead the construction of global ubiquitous market and induce the constant creation of demand.

And strategies fore future development and direction should be crafted from various perspectives as the social environment and system should cope with such a trend. Ubiquitous computing means that the border between the real space and virtual space is no more meaningful. It means that the virtual space is integrated naturally through the network. From the convergence of virtual space which IT companies embody in real space called 'architect' built by construction companies, new ubiquitous space is born, and digital home companies are breathing various vitality and vigor into it, making the lives of mankind more abundant and rich. This study emphasizes that the ubiquitous environment is imminent, considering the trend of study of global IT companies, the governmental policies of advanced IT countries, the changing social trend of business market, and the measure to cope with them is urgently required.

This study suggests the followings. First of all, building a just and transparent management system for the government and for enterprises is critical. Embodiment of a morally sound society through networking and computing is also important. Moreover, the basic direction of the Global Ubiquitous Market should be about building a system of innovation and creating new values. Strategies for propelling the Global Ubiquitous Market ought to set a vision for the coming ten years as well as to prepare a ubiquitous broadband network infrastructure that is a precondition for an optimum plan to build a system of innovation for countries and enterprises.

\section{REFERENCE}

1. Drucker, Peter, Managing in the Next Society, St. Martin's Press, 2002.

2. $\quad$ http://www.ubiq.com/(Ubiquitous Home Page, Xerox Palo Alto Research Center).

3. Hunter, Richard, World without Secrets: Business, Crime, and Privacy in the Age of Ubiquitous Computing, Gartner, Inc., 2002.

4. Information technology research institute, 2002.9) For the realization of Ubiquitous Network policy report, presented on 2002.6. (translated by ETRI (Electronics and Telecommunications Research Institute).

5. IT strategy headquarters of Japan, Report of new IT strategy research society(draft): u-Japan strategy 2004. 5(translated by Ha Won-Gyu, Yeon Seong-Joon, Park Sang-Hyeon of ETRI (Electronics and Telecommunications Research Institute).

6. Kim Wan-Seok, Park Tae-Wung, Lee Seong-Guk, Kim Jeong-Guk, and Baek Min-Gon, Ubiquitous Computing Strategy of IT Leaders and Hot Issues, KICS, Information and Communication Vol.20 No.5, 2003.6. 
7. Lee Seong-Guk, Comparative consideration of Ubiquitous Computing Strategy in US, Japan and Europe, Telecommunications Review, SK Telecom Vol.13 No.1, 2003.2.

8. Ministry of Internal Affairs and Communications, Japan, mid-term report for u-Japan policy session(data: ユビキタスネット社の現に向けた政策懇談), 2004.616. http://www.soumu.go.jp/s-news/2004/pdf/040701_1_b1.pdf.

9. Nomura Research Institute, Ubiquitous network and market creation, The Electronic Times Internet, 2002.

10. Nomura Research Institute, Ubiquitous network and new-society system, The Electronic Times Internet, 2003.

11. Research and study society on the future prospect of Ubiquitous Network Technology (Ministry of Internal Affairs and Communications, Japan).

12. Sakamura Ken, Ubiquitous computing innovation, Donbang Media, 2002.

13. Smart-Its Friends: A Technique for users to Easily Establish Connections between Smart Artefacts, http://www.inf.ethz.ch/vs/publ/papers/smf.pdf.

14. The journal of Pervasive and Ubiquitous Computing, http://www.personal-ubicomp.com.

15. Weiser, Mark and John Seely Brown. Designing Calm Technology. PowerGrid Journal, v1.01, July 1996.

16. Weiser, Mark, Computer Science Challenges for the Next Ten Years, (Xerox PARC) http://sandbox.xerox.com/Weiser/10year/sld001.htm.

17. Weiser, Mark, Hot Topic: Ubiquitous Computing, IEEE Computer, Pages 71-72, October 1993.

18. Weiser, Mark, The Computer for the Twenty-First Century, Scientific American, pp. 94-10, Sep 1991.

19. www.ta.doc.gov/Report.htm (Vision 2020 - Transforming Education and Training Through Advanced Technologies). 
International Business \& Economics Research Journal - April 2007

Volume 6, Number 4 NOTES 